of that period, where it is marked that in 1922 Advices of Labour and Defensive created in the system of Narkomatu of ways of report state steamship lines among which it was and Chernomorsko-azovske, and the Central rule of Derzhtorgflotu carried out general guidance their activity. In 1924 it was created unique point-of-sale-transport organization, which united transport ships, which belonged to different narkomatam, departments and joint-stock companies, including with a foreign capital. Then and centralized government a marine transport bases were founded as by the unique industry of national economy, not only ships, ports and dockyards, but also educational establishments entered in the infrastructure of which.

For more complete understanding of forming of marine education the stages of its development are described in a noted period, going near preparation of marine specialists of different type for providing of economic necessities of country, taking into account the features of geographical location of the Sonth region. Attention applies on the structure of curricula with pointing of blocks and disciplines which were obligatory for a study. Advice of Dnepr educational establishments, the representatives of Kherson tekhnikumu entered in which, was engaged in these questions, Oleshkivskoy and Golopristanskoy of nautical schools.

Biographic information of graduating students of tekhnikumu of soviet period, among which also there were navigators and sudnomekhaniki of ribopromislovogo fleet is given in research. Therefore it becomes firmly established in the article, that development of the system of marine education was in that time carried out in a horizontal plane.

Key words: marine education, educational establishments, marine specialists, tekhnikum, terms of studies, graduating students, education, disciplines, marine transport.

Дата надходження статті: 21.01.2020 p. Реценнзент: доктор педагогічних наук, доцент Чернявський В. В.

У, ДК 377:656.6(09)«19/20»(043.3)

DOI https://doi.org/10.37915/pa.vi45.81

Примакова В. В. ,

orcid.org/0000-0002-8914-6748

\title{
СПЕЦИФІКА РОЗВИТКУ ПРОФЕСІЙНОЇ КОМПЕТЕНТНОСТІ МАЙБУТНІХ МОРЯКІВ У ЗАКЛАДАХ МОРСЬКОЇ ОСВІТИ УКРАЇНИ (90-I РОКИ ХХ - ПОЧАТОК ХХІ СТОЛІТТЯ)
}

Метою публікациї є висвітлення актуальних проблем морської освіти в Україні, зокрема специфіки функціювання закладів освіти щодо забезпечення розвитку професійної компетентності в майбутніх моряків. Простежено зміни в змісті і завданнях підготовки здобувачів закладів морської освіти, виявлено комплекс чинників, що впливали на них упродовж аналізованого періоду.

У розвідияі обьрунтовано теоретико-методичні засади проблеми, схарактеризовано практичні кроки в напрямі реалізації компетентнісного підходу до освітньої діяльності майбутніх фахівців у вітчизняних закладах морської освіти. Студіювання поліаспектної джерельної бази з проблеми пошуку сприяло окресленню чіткого проблемного вектору та визначенню кола питань, щзо не отрихали достатнвого висвітлення. До них віднесено контентний аналіз ключових понять, виявлення конструктивного досвіду розбудови напряму впродовж етапу, що розглядається, пошук ефективних шляхів професіоналізації працівників морського флоту в умовах сьогодення.

У статті визначено характер зрушень стосовно здобутків $і$ перспектив забезпечення якісної підготовки майбутніх працівників морського профілю, що відбувалися на зламі

*C) Примакова В. В.

U3 221 
XX i XXI століть та простежено трансформацію підходів до вирішення нагальних проблем у иъьому пошуковому полі на сучасному етапі розбудови вітчизняної морської галузі.

Особливу увагу звернено на розвиток морської освіти в умовах міжнародної співпраці, впливу євроінтеграцій, світового досвіду на розроблення механізмів надання належної освіти та вирішення питань з подолання суперечностей, щзо виникають нині в національній системі відповідної підготовки.

Основними результатами вважаємо акцеент на формуванні в майбутніх моряків гнучких, універсальних (м'яких) навичок, поруч з вузькоспеціалізованими. До них віднесено: комунікативні, когнітивні та навички емоційного інтелекту. Їхній розвиток має забезпечити високий рівень виконання фахівиями професійної діяльності, оскільки сприятиме умінню конструктивного вирішення проблемних ситуацій, швидкої орієнтації в динамічному світі та вчасного реагування на зміни в нвому.

Ключові слова: морська освіта; професійна компетентність; універсальні навички; компетентнісний підхід, майбутні моряки; зміст і завдання.

Постановка проблеми. Морська освіта як необхідний складник національної системи освіти України має давні традиції та масштабний досвід у справі професійної підготовки молодого покоління моряків. Готовність до виконання цієї складної діяльності й опанування популярної нині переважно серед юнаків професії передбачає необхідність відповідності майбутніх моряків вимогам, що висуваються до їхніх знань, умінь і навичок. У різні часи професіограма моряка містила як спільні, так і відмінні риси, якості, компетентності, потрібні для роботи на морських судах різного типу. У пострадянський період розвитку морської освіти, зміст якої істотно відрізнявся від підходів, що домінували в підготовці фахівців радянського періоду, вимоги до кваліфікації моряка суттево змінювалися. У сучасному динамічному світі функції моряків постійно ускладнюються, що детермінує значне розширення й оновлення кола вимог до їхньої професійної кваліфікації.

Потужні зміни в змісті сучасної морської освіти зумовлені, передусім, важдивістю його приведення до міжнародних стандартів, оскільки Україна як морська держава в умовах інтеграції у світову спільноту свого часу стала активним учасником міжнародної взаємодії. Однак трансформація розвитку галузі не має обмежуватися запозиченням зарубіжного досвіду для продуктивної їі розбудови. Конструктивним напрямом небезпідставно визнається необхідність збереження при цьому кращих національних традицій і надбань. Підготовку конкурентоспроможної на міжнародному ринку праці та висококваліфікованої молоді продовжують здійснювати в закладах вітчизняної морської освіти, які останнім часом перебувають в умовах серйозної перебудови й інтенсивної модернізації.

Аналіз досліджень. Проблеми розвитку вітчизняної морської освіти в історичній ретроспективі глибоко досліджували А. Герганов, А. Аяшкевич, І. Рябуха, О. Чорний та ін. Різні аспекти питання професійної підготовки майбутніх моряків ретельно розглядали М. Бабишена, О. Фролова, Н. Черненко та ін. Аналіз різнопланових джерел з проблеми дав підстави стверджувати наявність потужного масиву напрацювань щодо розвитку морської освіти в Україні. Водночас він засвідчив потребу гдибокого вивчення особливостей підготовки майбутніх моряків у суперечдивий період здобуття країною незалежності, коли на тлі занепаду освіти в цілому та прогресивних змін у галузі система морської освіти зазнала суттевих трансформацій, які тривають і донині.

Мета статті - простеження специфіки розвитку морської освіти, зокрема підготовки майбутніх моряків на засадах компетентнісного підходу в період переорієнтації на потреби світової морської галузі (90-і роки XX - поч. XXI століття).

Виклад основного матеріалу. Формування i розвиток професійної компетентності майбутніх моряків здійснюеться через цілеспрямовану діядьність системи навчальних і позанавчальних закладів, культурно-освітніх установ

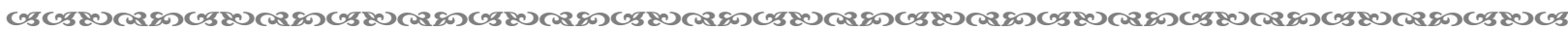
222 
та професійних інституцій з підготовки фахівців морської галузі в інтересах особистості, суспільства [3]. Виокремлюючи суттєві зміни, що відбувалися впродовж становлення і розбудови морської освіти, учені констатують, що теоретична і практична готовність курсантів на різних етапах забезпечувалася по-різному. Це залежало від різних чинників та переважно від комплексу фахових вимог та можливостей закладів морської освіти.

На основі комплексного ретроспективного анадізу розвитку морської освіти Півдня України в широких хронологічних межах А.Дяшкевич обгрунтувала авторську періодизацію. Основними періодами було названо: стихійно-установчий (1830-ті друга половина 1850-х рр.); перший реформаторський (друга половина 1850-х - початок 1870-х рр.); другий реформаторський (початок 1870-х - початок 1900-х рр.); законодавчий (початок 1900-х - 1920 рр.); пошуково-уніфікаційний (1920-1991рр.); наслідувально-оновлювальний (1991-2013 рр.), що виокремлювалися автором з урахуванням суспільно-політичних, економіко-правових та педагогічних детермінант [3]. Специфічність останнього періоду, виокремленого науковцем, привернула нашу увагу, оскільки він поєднував у собі орієнтацію на модернізацію системи в кардинально нових для країни і галузі умовах та намагання збереження традицій і здобутків минулого.

Простеживши тривалий шлях від епізодичого виникнення осередків освітньопрофесійного середовища морської освіти, за відсутності єдиної програми iï становлення на початку аналізованого періоду, до сучасної розбудови національної, якісно нової системи морської освіти (з паузою 1991-1995 рр.), А. Аяшкевич розкрила наскрізні змістові дінії розвитку морської освіти [3]. Зазначене дало підстави пов' язувати 90-і роки минулого століття 3 трансформаціями в змісті і методології підготовки майбутніх моряків, що носили як приклади деструктивного, так і зразки конструктивного вирішення проблем якісної професіоналізації працівників морської галузі.

Зазначений період взагалі переважна більшість дослідників пов'язують із багатьма освітніми нововведеннями. Зокрема, від початку дев'яностих років минулого стодіття в педагогічній теорії, а згодом і практиці, почали активно вживатися терміни «компетентність, компетентності, компетенції. Учені обгрунтовували контент дефініцій, активно обговорювали доцільність їх уживання в педагогічній лексиці.

Тогочасних освітян приваблювала новизна термінологіі, універсальність iï використання. Водночас теоретики заперечували їі новизну, простежуючи як відмінності, так і синонімічні зв'язки між ними та змістом суміжних понять «професіоналізм», «готовність до виконання діяльності», «знання, уміння і навички» [5]. Розуміння поняття «компетентність» у педагогіці тривалий час залишалося дискусійним, не достатньо узгодженим; воно і сьогодні має багато трактувань, оскільки визнається поліаспектним. Значного розроблення набула тоді проблема компетентнісного підходу й до розвитку морської освіти, зокрема в контексті підготовки висококваліфікованих моряків.

Загалом тогочасні нововведення не завжди носили системний характер, оскільки спрямування на стандартизацією підготовки майбутніх моряків відбувалося в незвичних умовах. До рівня компетентності фахівців торгівельного флоту висувалися нові вимоги, до забезпечення яких заклади морської освіти були не достатньо підготовлені.

Приєднання України до Міжнародної конвенції про підготовку і дипломування моряків та несення вахти 1978 року (з подальшими поправками) (ПДНВ) [4], а також ухвалення угод 3 безпеки судноплавства, відображених у низці документів, ратифікованих державою, суттєво змінило вектор розбудови і морської освіти.

Аналіз системи професійної підготовки кваліфікованих робітників морського флоту на початку третього тисячоліття, здійснений $А$. Гергановим, дав підстави стверджувати, що приведення змісту професійної компетентності робітників у відповідність до вимог роботодавців (судновласників), а також міжнародних документів, зміст яких містив нові вимоги до членів екіпажу морських суден, стало

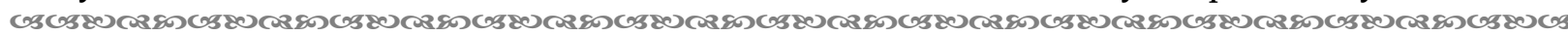
223 
вагомими підставами для змін в усій системі вітчизняної морської освіти. Від майбутніх моряків вимагали володіння сучасними методами та формами організації праці, засвоєння професійних вмінь і навичок роботи в реальних виробничих умовах. Дипломовані фахівці мали систематично розширювати свої знання та творчо використовувати їх у практичній діяльності, уміти ухвалювати самостійні рішення, розв'язувати проблеми й працювати в команді, бути готовим до перевантажень, стресових ситуацій тощо [1].

Продуктивними кроками в пошуках векторів розбудови морської освіти XXI століття вважалася контамінація ефективного досвіду минулого (через реактуалізацію основних здобутків і надбань) та впровадження інновацій (через опанування кращими новими розробленнями вітчизняного та зразками зарубіжного досвіду). Зазначене зумовило визначення нової стратегії в забезпеченні високого рівня професійної готовності майбутніх моряків, де знову однією з умов було окреслено орієнтир на реалізацію компетентнісного підходу.

Нині підготовка робітників морського профілю регламентується, крім національних нормативно-правових актів, ще й міжнародними, такими як: Міжнародна Конвенція про підготовку, дипломування моряків та несення вахти 1978 року (ПДНВ), що постійно доповнюється, постанови Кабінету Міністрів України, державні стандарти освіти та інші нормативні документи. Оскільки відповідно до положень Конституції України (ст. 9) чинні міжнародні договори визнано складниками національного законодавства, то першорядного значення на сучасному етапі набуває забезпечення розвитку й удосконалення професійної компетентності робітника морського профілю для виконання на високому рівні своїх професійних обов'язків. 3 огляду на вказане, А.Герганов потрактовуе професійну компетентність працівника морського профілю як систему, де ii формування забезпечуеться відповідністю національним і міжнародним вимогам. Науковцем розроблено авторську концепцію 3 професійної підготовки працівника морського профілю, що розглядається 3 позицій суб'єктнодіяльнісного, компетентнісного та системного підходів, у яких судноплавні компанії можуть реалізувати переваги умов виробництва [1].

Упровадження компетентнісного підходу до професійної підготовки моряків, що підвищуе рівень конкурентоздатності та мобільності робітника на ринку праці й зумовлено приписом, сформульованим у Національній стратегії розвитку освіти в Україні на 2012-2021 рр. та закріпленим Національною рамкою кваліфікацій, характеризується зміщенням акцентів в освітній парадигмі від технологічного до результативного ऑіі складника, від загальної до особистісної орієнтації та впровадження в навчальний процес інформаційно-комунікаційних технологій [1]. Тож друге десятиріччя XXI століття характеризується продовженням оновдення передіку вимог до професійної компетентності моряків та відповідно підходів до їі формування в закладах освіти. Відтак робиться акцент на тому, що суто знання, які складають основу професійної підготовки суднового персоналу, не завжди допомагають знайти оптимальний вихід із аварійних та небезпечних ситуацій.

Специфіка морської праці потребуе готовності членів екіпажу судна узгоджено діяти в екстремадьних ситуаціях, мати відповідний фізичний стан, уміти організувати працю і відпочинок, надавати вчасну допомогу членам екіпажу, ураховувати постійний вплив несприятливих чинників, володіти комплексом необхідних психічних властивостей: тривалістю уваги та вмінням розподіляти і концентрувати іiі, розвинутим просторовим мисленням, стійкою психікою й умінням миттєво й адекватно реагувати на проблемні ситуації [1].

Опікуючись вирішенням глобальних проблем розвитку морської освіти, сучасний працівник флоту має володіти не тільки комплексом вузькопрофесійних спеціальних знань, суто фахових умінь, а й універсальними (гнучкими, м'якими) навичками, вододіння якими передусім забезпечуе успішність виконання діядьності.

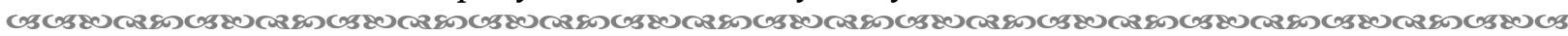
224 
Тож до вивчення цих питань долучидися сьогодні провідні науковці та перспективні дослідники.

Soft skills або «м'які навички», як такі, що передбачають уміння вирішувати складні проблеми, формувати в людини контекстне мислення, навички тонкої (ефективної) комунікації, прогнозування, стимулювати розвиток емоційного інтелекту є нині предметом вивчення багатьох вітчизняних (І. Бех, М. Меєрович, О. Савченко) і зарубіжних (Т. Бьюзен, М. Гафітулін, Ю. Тамберг) учених. Потенціал розвитку гнучких навичок особистості в швидкій адаптації до змін досліджувади А. Горлова, К. Коваль, Г. Чепурний та ін. У зв'язку зі змінами переліку основних компетентностей, що висуваються до здобувачів морської освіти та до їхньої професіограми в майбутньому, актуальності набувають проблеми формування в фахівців універсальних якостей і компетенцій.

Під м'якими навичками, за визначеннями сучасних науковців, розуміють комплекс неспеціалізованих, універсальних навичок, володіння якими сприяє успішній, активній участі фахівця в професійній діяльності, забезпечуючи іiі оптимадьність, високу ефективність, продуктивність, результативність. Називаючи такі навички «надпрофесійними», основною їхньою відмінністю від спеціалізованих, дослідники визнають відсутність нерозривного зв'язку із конкретною сферою вживання або застосування, адже вони допомагають особистості зростати в будь-якій сфері [6]. 3 огляду ж на специфіку професії моряка, яку відносять до розряду екстремальних, сформованість цих навичок набуває істотного значення.

Опанування м'якими навичками, передбачає забезпечення сформованості комунікативної компетентності, застосування потенціалу високої креативності, організації продуктивної командної роботи, здатності управління емоціями, а також стимулювання стійкої потреби в саморозвитку й самореалізації. У репрезентованій К. Коваль класифікації визначено такі основні групи м'яких навичок [2]: соціальнокомунікативні, когнітивні та такі, що становлять атрибути особистості і складники емоційного інтелекту.

До групи навичок першої категорії дослідницею включено комунікативні і міжособистісні навички, а також навички групової роботи, де приділяється особлива увага формуванню таких якостей: лідерство, відповідальність, етика міжособистісних відносин. Категорію когнітивних складають критичне мислення, навички вирішення проблемних ситуацій, нестандартне мислення, управління інтелектуальним навантаженням, оригінальність ідей, навички самоосвіти, медіаграмотність, таймменеджмент. Складниками третьої категорії названо ті особистісні якості, сформованість яких надає конструктивного акценту в обранні вектору будь-якої діяльності: емоційний інтелект, чесність, оптимізм, гнучкість, креативність, умотивованість, емпатію [там само]. Визнаючи важдивість кожного скдадника окресленої класифікації, зазначимо необхідність системного та неперервного розвитку кожної категорії soft skills майбутніх і дипломованих моряків у їхній освітній і професійній діяльності.

Морська освіта має потужний потенціал і певний досвід у напрямі вирішення цих завдань. Під час проходження практики, якій приділяеться багато часу, надається можливість професійного зростання засобами формування вищезазначених навичок. Зміст спеціально розроблених лекційних, семінарських і практичних занять 3 різних дисциплін, передбачених навчальними планами закладів морської освіти, містить необхідне спрямування щодо специфіки організації такої діядьності. Робота під час занять передбачає виконання системи вправ для опанування навичками командної роботи, акумулювання й упорядкування інформації, лідерської поведінки щодо ухвалення стратегічних рішень, критичного мислення та управління конфліктами.

Визначаючи налагодження тонкої комунікації основою успішної взаємодії членів команди, оскільки передбачае продуктивне міжособистісне спілкування, на перший

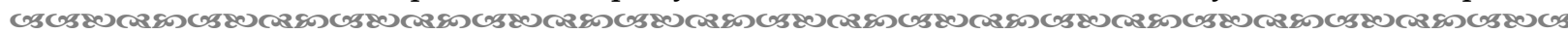
225 
план виступає формування комунікативних навичок. Якісною і продуктивнішою буде їхня професійна діяльність за умови опанування методами таймменеджменту, що забезпечують ефективне використання часу як найціннішого ресурсу в житті людини.

У процесі підготовки та оцінювання професійної компетентності в навчальних закладах морської галузі для відпрацювання професійних навичок широко використовують тренажери та тренажерні комплекси [1]. Завдяки створенню віртуального професійного середовища на тренажерному обладнанні курсант має можливість тренуватися в ухваленні остаточного рішення, удосконалювати швидкість та якість розумових і практичних дій, аналізувати їхні наслідки шляхом спроб і помилок.

Висновки. Ефективність забезпечення професійної підготовки майбутніх моряків на засадах компетентнісного підходу вбачаємо в контамінації конструктивного вітчизняного й інноваційного світового досвіду та його активному застосуванні в овододінні знаннями та практичними навичками. На сучасному етапі розвитку морської освіти продуктивною вважаємо діядьність відповідних закладів щодо розширення змісту підготовки системною роботою з опанування майбутніми моряками універсальними (м'якими навичками). До їхнього кола відносять навички функціональної грамотності особистості, розвиток яких сприяє швидкій адаптації до трансформацій, що відбуваються в динамічному світі. На відміну від вузькопрофесійних вони дають змогу кожному індивіду вільно орієнтуватися в конструктивних механізмах еводюції складно організованих систем, як у станах рівноваги, так і ентропії, а також у пошуках альтернативних шляхів вирішення проблем, прогнозування подальшого розвитку зазначених систем. Це підтверджує актуальність проблеми формування гнучких навичок у розвитку компетентності майбутніх працівників морської галузі.

Перспективними напрямами подальших досліджень визначаємо розгдяд можливостей системи морської освіти в забезпеченні якісної професійної підготовки майбутніх фахівців та розроблення навчально-методичного забезпечення, фундаментом якого було б поєднання реактуалізованого продуктивного досвіду минулого та найефективніших інновацій.

\section{Список використаних джерел:}

1. Герганов $А$.Д. Професійна підготовка кваліфікованих робітників морського профілю на виробництві: теорія і практика : монографія. К. : Педагогічна думка, 2012. С. 98-121.

2. Коваль К. Розвиток soft skills студента - один важдивих чинників працевластування. Вісник Вінницького похітехнічного інституту. 2015. № 2. С. 162-167.

3. Пяшкевич А. І. Організація морської освіти на півдні України в XIX - початку XXI століттях : монографія. Херсон : КВНЗ «Херсонська академія неперервної освіти», 2018. 478 с.

4. Міжнародна конвенція про підготовку і дипломування моряків та несення вахти 1978 року (консолідований текст з манільськими поправками). Київ : ВПК «Експрес- Поліграф», 2012. 568 c.

5. Примакова В. В. Післядипломна освіта вчителів початкових класів в Україні (середина XIX початок XXI століття): монографія. Херсон: КВНЗ «Херсонська академія неперервної освіти», 2014. 336 с.

6. Федорова О. В. Формирование hard skills, soft skills и digital skills у студентов факудьтета информационных технологий. УВО «Университет управления «ТИСБИ». Вестник «ТИСБИ». 2018. № 2. C. 335-341.

\section{References:}

1. Herhanov, L. D. (2012). Profesiina pidhotovka kvalifikovanykh robitnykiv morskoho profiliu na vyrobnytstvi: teoriia i praktyka [Vocational training of skilled marine workers in production: theory and practice]. Kyiv: Pedahohichna dumka [in Ukrainian]. 
2. Koval, K. (2015). Rozvytok soft skills studenta - odyn vazhlyvykh chynnykiv pratsevlastuvannia [The development of student soft skills is one of the important factors of employment]. Visnyk Vinnytskoho politekhnichnoho instytutu, 2, 162-167 [in Ukrainian].

3. Liashkevych, A. I. (2018). Orhanizatsiia morskoi osvity na pivdni Ukrainy v 19 - pochatku 21 stolittiakh [Organization of marine's education in the south of Ukraine in the 19 - beginning 21 centuries]. Kherson: KVNZ "Khersonska akademiia neperervnoi osvity" [in Ukrainian].

4. Mizhnarodna konventsiia pro pidhotovku i dyplomuvannia moriakiv ta nesennia vakhty 1978 roku (konsolidovanyi tekst $\mathrm{z}$ manilskymy popravkamy) [International Convention on the Training and Certification of Seafarers and Watchkeeping, 1978 (consolidated text, with amended)]. (2012). Kyiv: VPK “Ekspres- Polihraf" [in Ukrainian].

5. Prymakova, V. V. (2014). Pisliadyplomna osvita vchyteliv pochatkovykh klasiv v Ukraini (seredyna 19 pochatok 21 stolittia) [Postgraduate education of primary school teachers in Ukraine (mid-19th beginning of 21st century)]. Kherson: KVNZ «Khersonska akademiia neperervnoi osvity» [in Ukrainian].

6. Fedorova, O. V. (2018). Formyrovanye hard skills, soft skills y digital skills u studentov fakulteta ynformatsyonnukh tekhnolohyi UVO [Formation of hard skills, soft skills and digital skills in students of the Faculty of Information Technology]. Unyversytet upravlenyia "TYSBY". Vestnyk "TYSBY", 2, 335-341 [in Russian].

Prymakova V. V. orcid.org/0000-0002-8914-6748

\section{SPECIFICITY OF DEVELOPMENT FUTURE SEALERS' PROFESSIONAL COMPETENCE IN UKRAINIAN MARITIME EDUCATIONAL INSTITUTIONS (90TH YEARS OF XXTH - BEGINNING OF XXIST CENTURY)}

The purpose of the publication is to highlight the current problems of maritime education in Ukraine, in particular the specifics of the functioning of educational institutions to ensure the development of professional competence in future sealers. Changes in the content and tasks of preparation of applicants for maritime education have been monitored, a set of factors that have influenced them during the analyzed period has been identified.

In the article substantiates the theoretical and methodological foundations of the problem, describes the practical steps in the direction of implementing a competent approach to the educational activities of future specialists in Ukrainian maritime educational institutions. Studying a polyaspectic source base on a search problem helped to identify a clear problem vector and identify a range of problems that did not receive sufficient coverage. These include a content analysis of key concepts, the identification of a constructive experience of building a direction during the current stage, the search for effective ways to professionalize the Navy in the present.

The article identifies the nature of the shifts in the achievements and prospects of quality training for future sailors in the XXth and XXIst centuries and traces the transformation of approaches to solving urgent problems in this problem field at the present stage of development of Ukrainian maritime industry.

Particular attention is paid to the development of maritime education in the context of international cooperation, the impact of European integration, world experience on the development of mechanisms for the providing of proper education, and the resolution of issues that currently arise in the national system of education.

The main results are the emphasis on the formation of future sailors, along with highly specialized skills, flexible, soft skills. These include: communicative, cognitive and emotional skills. Their development should ensure a high level of fulfillment by future professionals of professional activity, as it will contribute to the ability to constructively solve problematic situations, to quickly orient in a dynamic world and to respond promptly to changes in it.

Key words: maritime education; professional competence; universal skills; competence approach, future sailors; content and tasks. 